\title{
NANOTECHNOLOGIA A OCHRONA ŚRODOWISKA - PERSPEKTYWA PRAWNA
}

\section{WPROWADZENIE}

Nanotechnologia oznacza projektowanie i wytwarzanie struktur, w których przynajmniej jeden rozmiar jest poniżej 100 nanometrów (nm) i które posiadają nowe właściwości wynikające z nanorozmiaru ${ }^{1}$. Zgodnie z rezolucja Parlamentu Europejskiego „Aspekty regulacyjne nanomateriałów” stosowanie nanomateriałów stwarza nadzieję na istotny postęp wraz z licznymi korzyściami w różnorodnych zastosowaniach, ponieważ nanomateriały mogą charakteryzować się odmiennymi lub nowymi właściwościami w porównaniu z ta samą substancją lub materiałem w konwencjonalnej postaci; z drugiej jednak strony, ze względu na swoje mikroskopijne rozmiary, nanomateriały potencjalnie stwarzają istotne nowe zagrożenia, np. zwiększoną reaktywność i mobilność, co może skutkować wzrostem toksyczności. Wyzwaniem w kontekście

${ }^{1}$ R. Michalczewski, A. Mazurkiewicz, Analiza pojęciowa nanonauk $i$ nanotechnologii, w: A. Mazurkiewicz (red.), Nanonauki i nanotechnologie. Stan i perspektywy rozwoju, Radom 2007, s. 23; podstawowymi zastosowaniami nanotechnologii sa: zaawansowane materiały (budowlane, termoizolacje, aerożele, materiały dla przemysłu motoryzacyjnego i celów militarnych); energetyka (wytwarzanie energii ze źródeł odnawialnych: baterii słonecznych i ogniw paliwowych oraz magazynowanie i oszczędność energii); elektronika (półprzewodniki, pamięci masowe, systemy nanoelektromechaniczne); technologie IT (systemy zapisu, przetwarzania i transmisji danych, wielofunkcyjne urządzenia telekomunikacyjne, komputery kwantowe); optyka i optoelektronika (lasery, wyświetlacze, diody laserowe, sprzęt optyczny z powłokami funkcjonalnymi); farmacja (leki stabilizowane nanocząstkami, materiały opatrunkowe, nanokapsułki); diagnostyka i sprzęt medyczny (urządzenia lab-on-chip - systemy zintegrowanych mini laboratoriów, systemy dozowania leków, obrazowanie o wysokiej rozdzielczości, diagnostyka, protezy i implanty); kosmetyki (filtry UV, kremy, środki higieny osobistej); opakowania (podwyższające przydatność do spożycia, biodegradowalne, recykling opakowań); produkcja żywności (czujniki monitorujące przydatność do spożycia, żywność pozostająca nieaktywną w organizmie i uwalniająca się wraz z dostarczaniem substancji odżywczych dopiero po dotarciu do określonych komórek, dodatki do żywności); artykuły tekstylne i sportowe (funkcjonale materiały tekstylne, sprzęt i sportowe materiały eksploatacyjne); ograniczanie emisji zanieczyszczeń (usuwanie i neutralizacja zanieczyszczeń, wykrywanie skażeń, ekologiczna produkcja i energia, przetwarzanie odpadów) i uzdatnianie wody (membrany do filtracji wody, technologie odsalania) - R. Wawrzyński, W. Karsznia, Zastosowania nanotechnologii, w: A. Mazurkiewicz (red.), Nanonauki i nanotechnologie. Stan i perspektywy rozwoju, Radom 2007, s. 262, 279 i 285.

2 Rezolucja Parlamentu Europejskiego „Aspekty regulacyjne nanomateriałów”, Dz. Urz. UE C 184 z 8 lipca 2010 r., s. 82. 
uregulowań prawnych, według komunikatu Komisji Europejskiej „Aspekty regulacyjne nanomateriałów”, jest więc zapewnienie społeczeństwu możliwości korzystania z nowych zastosowań nanotechnologii przy jednoczesnym zagwarantowaniu bezpieczeństwa, ochrony zdrowia i środowiska. Problem naukowy stanowi niedobór wiedzy dotyczącej technik wykrywania, pomiarów i charakteryzowania nanomateriałów, ich monitorowania i danych na temat ich toksyczności; wiedza ta tworzy podwaliny regulacji prawnych. W rezultacie uregulowania prawne UE fragmentarycznie, wycinkowo odnoszą się do zabezpieczenia ochrony środowiska w odniesieniu do innowacyjnych zastosowań nanotechnologii.

Celem artykułu jest ukazanie aktualnego stanu regulacji prawnych UE dotyczących ochrony środowiska w kontekście innowacyjnych zastosowań nanotechnologii oraz ujawnienie uchybień prawodawstwa UE w tym obszarze, a także wskazanie kierunków jego zmian służących zapewnieniu ochrony środowiska.

\section{UREGULOWANIA PRAWNE KWESTII OCHRONY ŚRODOWISKA W ASPEKCIE NANOMATERIAŁÓW}

W literaturze przedmiotu stwierdza się, iż rozwój nanotechnologii może przynieść korzyści dla ludzkości, lecz należy pamiętać również o ewentualnym zagrożeniu. Powinno się podjąć intensywne działania w zakresie stworzenia sprawnego systemu prawnego i efektywnych mechanizmów monitorowania oraz identyfikacji potencjalnych dróg narażenia ${ }^{4}$. Niektóre ograniczenia w zakresie nanomateriałów wynikaja głównie z braku wiedzy i możliwości technicznych (w szczególności technik wykrywania i monitorowania), a w określonych przypadkach z powodu niemożliwości stosowania istniejących mechanizmów prawnych (tj. progi stężeń w celu kontroli obecności zanieczyszczeń) ${ }^{5}$. Jedną z przeszkód w zarządzaniu ryzykiem w nanotechnologii, zgodnie z prawem UE dotyczącym ochrony środowiska, jest brak narzędzi służących metrologii. Metody i technologie wykrywania, pomiaru i charakteryzowania materiałów w nanoskali są wciąż opracowywane ${ }^{6}$. Nadal istnieją luki w wiedzy naukowej odnośnie do toksyczności i zachowania nanomateriałów w komponentach środowiska, które utrudniają skuteczne wdrożenie unijnego dorobku prawnego dotyczące-

${ }^{3}$ Komunikat Komisji Europejskiej „Aspekty regulacyjne nanomateriałów”, $\operatorname{COM(2008)~} 366$ z 17 czerwca $2008 \mathrm{r}$.

${ }^{4}$ A. Baran, Prawne aspekty nanotechnologii w kontekście ochrony środowiska, „Ekonomia i Środowisko" 52, 2015, nr 1, s. 39.

${ }^{5}$ Milieu Ltd., AMEC Environment \& Infrastructure UK Ltd., Review of Environmental Legislation for the Regulatory Control of Nanomaterials, <ec.europa.eu/environment/chemicals/nanotech/pdf/review_legislation.pdf> [dostęp: 17.08.2017].

${ }^{6}$ L.K. Breggin, J. Pendergrass, Regulation of nanoscale materials under media-specific environmental laws, w: G.A. Hodge, D.M. Bowman, A.D. Maynard (eds.), International Handbook on Regulating Nanotechnologies, Cheltenham, Northampton 2010, s. 359. 
go ochrony środowiska w odniesieniu do tego rodzaju substancji chemicznych. Podstawowe znaczenie dla określenia cech nanomateriałów, a także wszelkich zagrożeń lub ryzyka wynikajacych ze struktury materiału w nanoskali maja metody testów. Dostępne metody testów powinny zostać poddane przeglądowi oraz - w stosownych przypadkach - jak najszybciej zaktualizowane; należy również opracować nowe metody wypełniające luki w metodach testów?

Kluczowa bariera w stosowaniu prawa dotyczącego ochrony środowiska regulującego materiały w nanoskali sa progi oparte na ilości. W wielu przypadkach, jeżeli progi te nie sa osiagane, prawo nie ma zastosowania lub nakłada ograniczone wymogi. Progi te zwykle mają uzasadnienie w kontekście konwencjonalnych materiałów, jako że minimalna ilość zanieczyszczeń często nie jest objęta uregulowaniami prawnymi. Przez zapewnienie takich zwolnień prawo może być skuteczniej stosowane, środki zaś poświęcone na wyeliminowanie najpoważniejszego ryzyka. W kontekście uregulowań prawnych w nanotechnologii takie zwolnienia oparte na masie moga jednak uniemożliwić regulację tam, gdzie jest ona stosowna ${ }^{8}$. Specyficzne właściwości nanomateriałów oznaczaja, że stężenia wyrażone na podstawie masy i stosowane do ustalania progów nie są precyzyjne w odniesieniu do nanomateriałów, ponieważ badania toksykologiczne wskazuja, że toksyczność wzrasta wraz ze zmniejszonymi ich wymiarami ${ }^{9}$. Monitorowanie środowiska $\mathrm{z}$ reguły bazuje na masie, ale zamiast masy liczba cząstek lub powierzchnia mogą być bardziej odpowiednie do pomiaru oddziaływania czastek w nanoskali na zdrowie i środowisko ${ }^{10}$. Zgodnie z rezolucją Parlamentu Europejskiego „Aspekty regulacyjne nanomateriałów” istnieje potrzeba przeprowadzenia przeglądu dopuszczalnych wartości emisji i środowiskowych norm jakości w przepisach dotyczących powietrza i wody celem uzupełnienia pomiarów opartych na masie przez systemy pomiarowe bazujące na liczbie cząstek lub powierzchni, aby odpowiednio uwzględnić nanomateriały; ponadto wskazane jest dokonanie przeglądu dopuszczalnych wartości emisji dla spalania odpadów również w celu uzupełnienia pomiarów opartych na masie przez systemy pomiarowe zależne od liczby cząstek lub powierzchni ${ }^{11}$.

${ }^{7}$ Ricardo Energy \& Environment, Milieu Ltd., Danish Technical University, Support for 3rd regulatory review on nanomaterials - environmental legislation, <orbit.dtu.dk/files/130663951/ Broomfield_et_al._2016.pdf> [dostęp: 17.08.2017].

${ }^{8}$ L.K. Breggin, J. Pendergrass, op. cit., s. 360.

${ }^{9}$ Milieu Ltd., AMEC Environment \& Infrastructure UK Ltd., op. cit.

${ }^{10}$ L.K. Breggin, J. Pendergrass, op. cit., s. 359.

${ }^{11}$ Zob. załącznik XI i załącznik XIV do dyrektywy Parlamentu Europejskiego i Rady 2008/50/WE w sprawie jakości powietrza i czystszego powietrza dla Europy (Dz. Urz. UE L 152 z 11 czerwca 2008 r., s. 1 ze zm.); załącznik I do dyrektywy Parlamentu Europejskiego i Rady 2008/105/WE w sprawie środowiskowych norm jakości w dziedzinie polityki wodnej, zmieniającej i w następstwie uchylajaccej dyrektywy Rady 82/176/EWG, 83/513/EWG, 84/156/EWG, 84/491/EWG i 86/280/ EWG oraz zmieniającej dyrektywę 2000/60/WE Parlamentu Europejskiego i Rady (Dz. Urz. UE L 348 z 24 grudnia 2008 r., s. 84 ze zm.); załącznik I do dyrektywy Parlamentu Europejskiego i Rady 2006/118/WE w sprawie ochrony wód podziemnych przed zanieczyszczeniem i pogorszeniem ich stanu (Dz. Urz. UE L 372 z 27 grudnia 2006 r., s. 19 ze zm.) oraz załącznik VI do dyrektywy Parlamentu Europejskiego i Rady 2010/75/UE w sprawie emisji przemysłowych (Dz. Urz. UE L 334 z 17 grudnia 2010 r., s. 17 ze zm.). 
Ponadto rozporządzenie Parlamentu Europejskiego i Rady 1907/2006/WE w sprawie rejestracji, oceny, udzielania zezwoleń i stosowanych ograniczeń w zakresie chemikaliów i utworzenia Europejskiej Agencji Chemikaliów, zmieniające dyrektywę 1999/45/WE i uchylające rozporządzenie Rady 793/93/EWG oraz rozporządzenie Komisji 1488/94/WE, jak również dyrektywę Rady 76/769/EWG i dyrektywy Komisji 91/155/EWG, 93/67/EWG, 93/105/WE i 2000/21/WE (rozporządzenie REACH) ${ }^{12}$ oraz rozporządzenie Parlamentu Europejskiego i Rady 1272/2008/WE w sprawie klasyfikacji, oznakowania i pakowania substancji i mieszanin (rozporządzenie CLP) ${ }^{13}$ sa przeważnie bezużyteczne, jeśli chodzi o zapewnienie odpowiedniego zarządzania i nadzoru nad nanomateriałami. Jedną z przyczyn takiej sytuacji jest fakt, że wdrożenie większości istniejących przepisów prawa UE w odniesieniu do nanomateriałów jest uzależnione od obecnie niedostępnych informacji i danych ${ }^{14}$. Rozporzadzenie REACH i rozporządzenie CLP nie zawieraja przepisów szczególnych nawiązujących do substancji chemicznych w formie nanomateriału. Rozporządzenia te nie stanowią więc odpowiedniej bazy do kontroli wpływu nanomateriałów na środowisko.

Zgodnie z komunikatem Komisji Europejskiej „Aspekty regulacyjne nanomateriałów" rozporządzenie REACH jest ogólnym aktem prawnym majacym zastosowanie do produkcji, wprowadzania do obrotu i wykorzystywania poszczególnych substancji chemicznych w ich postaci własnej oraz wchodzących w skład mieszanin lub produktów; zakres definicji substancji zawartej w rozporządzeniu REACH obejmuje także nanomateriały. Charakterystyka ryzyka wiążącego się z nanomateriałami może zależeć od wielkości cząstki lub funkcjonalizacji powierzchni, określenie więc dokładnego zakresu, wskaźników dawki oraz poziomu wszelkich wartości progowych stosowanych w przepisach z zakresu ochrony środowiska stanowi większe wyzwanie niż w przypadku konwencjonalnych zanieczyszczeń; system REACH powinien być źródłem należytych danych na ten temat. Głównymi mechanizmami umożliwiającymi identyfikację czynników zanieczyszczających środowisko są: klasyfikacja zagrożenia według rozporządzenia CLP oraz informacje na temat narażenia. Wciąż w znacznym stopniu brak jest danych dotyczących narażenia na nanomateriały za pośrednictwem środowiska ${ }^{15}$. Ograniczenia zarówno danych dotyczących zagrożenia, jak i narażenia odnośnie do konkretnych nanomateriałów utrudniają ocenę potencjalnego ryzyka wiążącego się z nanomateriałami. Natomiast brak klarownego i kompleksowego przeglądu ryzyka stwarzanego przez nanomateriały powoduje, że wyzwanie stanowi określenie zarówno luk w zakresie wprowadzania uregulowań prawnych, jak i faktycznego niedopasowania ram prawnych ${ }^{16}$. Stwierdza się, że rozwój ogólnoeuropejskiej bazy

12 Dz. Urz. UE L 396 z 30 grudnia 2006 r., s. 1 ze zm.

13 Dz. Urz. UE L 353 z 31 grudnia 2008 r., s. 1 ze zm.

${ }_{14}$ D. Azoulay, Regulating nanomaterials - EU shifting the burden, <https://chemicalwatch. com/48773/regulating-nanomaterials-eu-shifting-the-burden> [dostęp: 17.08.2017].

15 Komunikat Komisji Europejskiej „Drugi przegląd regulacyjny poświęcony nanomateriałom”, $\operatorname{COM(2012)~} 572$ z 3 października 2012 r.

${ }^{16}$ Milieu Ltd., AMEC Environment \& Infrastructure UK Ltd., op. cit. 
danych dotyczacych produkcji i importu nanomateriałów (wzorem rejestru substancji w nanoskali wprowadzonego we Francji) przyniósłby korzyści w zakresie badań na temat ryzyka dla środowiska. Przydatne byłoby, aby taka baza danych dostarczała ilościowych danych na temat przeznaczenia objętych nią nanomateriałów ${ }^{17}$. We Francji rejestr substancji w nanoskali ${ }^{18}$ ma na celu pogłębienie wiedzy na temat tych substancji i ich zastosowań. Każdy producent, importer i dystrybutor substancji w nanoskali składa deklarację, jeśli produkuje, importuje lub dystrybuuje co najmniej 100 gramów tej substancji rocznie; deklarację tę kieruje się do Ministra Środowiska corocznie przed 1 maja (art. R. 523-13). Deklaracja musi zawierać: dane zgłaszającego; tożsamość substancji w nanoskali; ilość tej substancji wyprodukowanej, rozprowadzonej lub importowanej w ciągu roku objętego deklaracja - wyrażona w kilogramach; zastosowania substancji w nanoskali oraz dane profesjonalnych użytkowników, którym zgłaszający przekazał substancję w nanoskali ${ }^{19}$.

Większość unijnych aktów prawnych odnoszaccych się do ochrony środowiska nie uwzględnia w wystarczającym stopniu nietypowych właściwości nanomateriałów oraz wszelkich potencjalnych zagrożeń, które mogą być związane z tymi właściwościami. Jednym z głównych powodów jest fakt, że rozporządzenie REACH i rozporządzenie CLP nie określają ani nie generuja skutecznie informacji o nanomateriałach, podczas gdy duża część prawa dotyczącego środowiska (np. odpadów, wody, emisji do powietrza) opiera się na tych dwóch instrumentach w celu uruchomienia środków zarządzania ryzykiem względem substancji chemicznych stwarzających zagrożenie ${ }^{20}$. Wobec braku dostępnych danych specyficznych dla nanomateriałów, zgodnie z rozporządzeniami CLP, są one zasadniczo klasyfikowane według formy konwencjonalnej substancji chemicznej i w niektórych przypadkach właściwości niebezpieczne mogą nie zostać rozpoznane. Oznaczałoby to, że szereg przepisów w dziedzinie ochrony środowiska, które służą kontrolowaniu uwalniania do środowiska substancji stwarzających zagrożenie, nie byłoby stosowanych w odniesieniu do konkretnych nanomateriałów ${ }^{21}$. W zakresie rozporządzenia CLP akcentuje się potrzebę określenia kryteriów charakterystyki, nadawania różnych klasyfikacji różnym postaciom nanomateriałów, a także ponownej oceny kryteriów klasyfikacji w odniesieniu do nanomateriałów ${ }^{22}$. Rozporządzenie REACH może nie generować wystarczających danych odnoszących się do nanomateriałów, gdyż wymogi dotyczace rejestracji REACH opierają się w dużej mierze na ilo-

${ }^{17}$ Ricardo Energy \& Environment, Milieu Ltd., Danish Technical University, op. cit.

${ }^{18}$ Decree no. 2012-232 on the annual declaration on substances at nanoscale in application of article R. 523-4 of the Environment code, „Official Journal of the French Republic” Text 4/44, 19.02.2012.

${ }^{19}$ Ministerial Order of 6.08.2012 on the content and the conditions for the presentation of the annual declaration on substances at nanoscale in application of articles R. 523-12 and R. 523-13 of the Environment code (Appendix).

${ }^{20}$ Ricardo Energy \& Environment, Milieu Ltd., Danish Technical University, op. cit.

${ }^{21}$ Milieu Ltd., AMEC Environment \& Infrastructure UK Ltd., op. cit.

${ }^{22}$ M. Heinälä, H. Stockmann-Juvala, CLP Regulation and Nanomaterial Classification A Preliminary Review of GHS and Possible Problem Identification: Nordic Stakeholder Survey on Nanomaterial Hazard Classification and Labelling, Copenhagen 2014, s. 3. 
ści wytwarzanej substancji i zostały sporządzone głównie w relacji do konwencjonalnych chemikaliów ${ }^{23}$. Według art. 6 ust. 1 rozporządzenia REACH każdy producent lub importer substancji, w jej postaci własnej lub jako składnika jednego bądź większej liczby mieszanin, w ilości co najmniej 1 tony rocznie przedkłada Europejskiej Agencji Chemikaliów (ECHA) dokumenty rejestracyjne. Tradycyjne zwolnienia oparte na wielkości produkcji sa krytykowane, ponieważ umieszczają wiele nanomateriałów, które są produkowane w niewielkich ilościach, poza wymogami przepisów ${ }^{24}$. Poza tym zgodnie z art. 12 ust. 1 rozporządzenia REACH szczegółowość informacji dotyczących substancji, które należy przedłożyć, wzrasta wraz ze zwiększeniem wielkości obrotu.

Dynamiczny postęp w obszarze nanotechnologii i jej interdyscyplinarne zastosowania powoduja, że prawodawstwo UE ulega częstym zmianom. Istotne w kontekście uregulowań prawnych UE w sferze nanotechnologii jest więc tzw. miękkie prawo UE (soft law). Podstawową zaletą miękkiego prawa UE jest to, że z jednej strony umożliwia ono większą elastyczność, jest mniej sformalizowane, łatwiej je zmienić bądź uchylić, z drugiej - jest ono wykonywane ze względu na prestiż instytucji, która je przyjęła ${ }^{25}$. Wiele obecnie istniejących ponadnarodowych programów miękkiego prawa ma na celu rozwiazywanie problemów związanych z ochrona środowiska, zdrowia i bezpieczeństwa w kontekście wykorzystywania innowacyjnych zastosowań nanotechnologii ${ }^{26}$. Kodeksy, wytyczne, komitety doradcze, standardy, zachęty, stowarzyszenia zawodowe lub handlowe, obowiązkowe lub dobrowolne systemy akredytacji oraz systemy informacyjne, tj. ustalenia dotyczace składania sprawozdań, sa również narzędziami regulacyjnymi ${ }^{27}$.

Zalety miękkiego prawa czynią je atrakcyjnym w kontekście wspomagania zarządzania nanotechnologia. W szczególności programy miękkiego prawa mogą zostać skorygowane stosunkowo szybko w odpowiedzi na zmieniające się okoliczności, ponieważ nie ma potrzeby przechodzenia przez formalne procedury stanowienia przepisów, jakie są wymagane w przypadku tradycyjnych regulacji prawnych. Wiele programów miękkiego prawa jest opracowywanych i prowadzonych w ramach modelu współpracy, który może zachęcać zarówno do uczestnictwa, jak i dialogu między stronami ${ }^{28}$. Programy miękkiego prawa mają zdolność do wspierania tworzenia i aktywizacji norm zachowania wśród docelowej grupy przedsiębiorstw. Przedsiębiorstwo może także stracić korzyści, jeśli nie spełnia standardów wymaganych przez programy soft law, np. programy certyfikacji. Programy mają konkretny cel - oddziaływanie na sposób, w jaki przedsiębiorstwa i osoby fizyczne stosują nanotechnologię i zarządzają

${ }^{23}$ L.K. Breggin, J. Pendergrass, op. cit., s. 362 i 364.

${ }^{24} \mathrm{M}$. Widmer, C. Melli, Approaching the nanoregulation problem in chemicals legislation in the EU and US, w: G.A. Hodge, D.M. Bowman, A.D. Maynard (eds.), op. cit., s. 263.

25 A. Wyrozumska, Pojęcie prawa UE i jego źródta, w: J. Barcz, M. Górka, A. Wyrozumska (red.), Instytucje i prawo Unii Europejskiej, Warszawa 2012, s. 244-245.

${ }^{26}$ G.E. Marchant, K.W. Abbott, International Harmonization of Nanotechnology Governance through “Soft Law” Approaches, „Nanotechnology Law \& Business” 9(4), 2013, s. 410.

27 L. Brazell, Nanotechnology Law. Best Practices, Alphen aan den Rijn 2012, s. 91.

28 G.E. Marchant, K.W. Abbott, op. cit., s. 398. 
nią. Miękkie prawo może posłużyć jako podstawa do opracowania instrumentów prawnie wiążących; często ma to formę dobrowolnych programów mających na celu zebranie informacji potrzebnych do podejmowania decyzji regulacyjnych $^{29}$. Elastyczność takich mechanizmów może pomóc w znalezieniu najbardziej realnej równowagi pomiędzy konkurującymi wartościami różnych grup interesów ${ }^{30}$. Miękkie prawo jest również pomocne przy wdrażaniu istniejących instrumentów prawnie wiążących. Jednym z powszechnie stosowanych narzędzi miękkiego prawa wykorzystywanym w tym celu są nieformalne poradniki wydawane w celu wyjaśnienia interpretacji regulacji prawnych; podobnie programy pomocy technicznej w formie szkoleń, warsztatów i wizyt w terenie ${ }^{31}$.

\section{NAWIĄZANIA DO NANOTECHNOLOGII W AKTACH PRAWNYCH UE DOTYCZĄCYCH OCHRONY ŚRODOWISKA}

Przepisy prawa UE odwołujące się do nanotechnologii w odniesieniu do ochrony środowiska ustanowiono względem sprzętu elektrycznego i elektronicznego, środowiska wodnego oraz nieobowiązkowego programu oznakowania ekologicznego. Uregulowania te, wprowadzone w ostatnich latach, służa wzmocnieniu bezpieczeństwa zastosowania nanotechnologii dla zdrowia ludzkiego i środowiska. Ich praktyczne funkcjonowanie będzie mogło zostać kompleksowo zbadane w dłuższej perspektywie czasowej, gdyż dotychczas (poza dobrowolnym programem oznakowania ekologicznego) nie zostały one zastosowane względem nanomateriałów.

Dyrektywa Parlamentu Europejskiego i Rady 2008/105/WE w sprawie środowiskowych norm jakości w dziedzinie polityki wodnej, zmieniająca i w następstwie uchylajacca dyrektywy Rady 82/176/EWG, 83/513/EWG, 84/156/EWG, 84/491/EWG i 86/280/EWG oraz zmieniajacca dyrektywę 2000/60/WE Parlamentu Europejskiego i Rady ${ }^{32}$ nawiązuje w art. 8b ust. 1 do parametru wielkości cząstek; Komisja Europejska sporządza listę obserwacyjną substancji, w odniesieniu do których mają być gromadzone dane z monitorowania obejmujace całą UE w celu szeregowania substancji do dokonania przeglądu Wykazu substancji priorytetowych w dziedzinie polityki wodnej (załącznik X do dyrektywy Parlamentu Europejskiego i Rady 2000/60/WE ustanawiającej ramy wspólnotowego działania w dziedzinie polityki wodnej ${ }^{33}$ ); lista obserwacyjna zawiera maksymalnie 14 substancji lub grup substancji; substancje, które mają być

${ }_{29}$ T.F. Malloy, Soft Law and Nanotechnology: A Functional Perspective, <https://www.technologylawsource.com/files/2012/04/Soft-Law-and-Nanotechnology-A-Functional-Perspecti.pdf> [dostęp: 20.11.2017].

${ }^{30}$ L. Brazell, op. cit., s. 91.

31 T.F. Malloy, op. cit.; na temat aktualnych regulacji prawnych UE w nanotechnologii zob. M. Jurewicz, Kilka uwag na temat aktualnego stanu uregulowań prawnych UE w obszarze nanotechnologii, „Prawo Europejskie w Praktyce” 143, 2016, nr 5, s. 39-42.

32 Dz. Urz. UE L 348 z 24 grudnia 2008 r., s. 84 ze zm.

${ }^{33}$ Dz. Urz. UE L 327 z 22 grudnia 2000 r., s. 1 ze zm. 
umieszczone na liście obserwacyjnej, są wybierane spośród tych, w odniesieniu do których dostępne informacje wskazuja, że mogą one przedstawiać na poziomie UE znaczne ryzyko dla środowiska wodnego lub za jego pośrednictwem, i w odniesieniu do których dane z monitorowania sa niewystarczające; przy kwalifikowaniu substancji do listy obserwacyjnej Komisja Europejska uwzględnia wszystkie dostępne informacje, w tym: wyniki najbardziej aktualnego regularnego przeglądu załącznika X do dyrektywy 2000/60/WE; projekty badawcze; zalecenia zainteresowanych stron; charakterystyki obszaru dorzecza i wyniki programów monitorowania państw członkowskich UE oraz wielkość produkcji, sposoby użytkowania, swoiste właściwości (w tym w stosownych przypadkach wielkości czasstek), stężenia w środowisku i skutki.

Według motywu 18 preambuły do dyrektywy Parlamentu Europejskiego i Rady 2012/19/UE w sprawie zużytego sprzętu elektrycznego i elektronicznego ${ }^{34}$ narażenie na nanomateriały, które są trwale umocowane w dużych strukturach, np. w obwodach elektronicznych, może wystapić w fazie odpadu i podczas recyklingu; aby kontrolować ewentualne ryzyko dla zdrowia ludzkiego i dla środowiska wynikające z przetwarzania zużytego sprzętu elektrycznego i elektronicznego zawierajaccego nanomateriały, Komisja Europejska powinna ocenić, czy właściwe przetwarzanie może okazać się niezbędne. Komisja Europejska, zgodnie $\mathrm{z}$ art. 8 ust. 4 , jest proszona o dokonanie oceny, czy zmiany w załączniku VII są konieczne w odniesieniu do nanomateriałów zawartych w sprzęcie elektrycznym i elektronicznym; załącznik VII dotyczy selektywnego przetwarzania materiałów i części składowych zużytego sprzętu elektrycznego i elektronicznego.

Według art. 4 ust. 1-2 dyrektywy Parlamentu Europejskiego i Rady 2011/65/UE w sprawie ograniczenia stosowania niektórych niebezpiecznych substancji w sprzęcie elektrycznym i elektronicznym ${ }^{35}$ państwa członkowskie UE zapewniaja, aby wprowadzony do obrotu sprzęt elektryczny i elektroniczny, włącznie z przewodami i częściami zamiennymi służącymi do jego naprawy lub ponownego użycia, aktualizacji jego funkcjonalności lub zwiększenia jego możliwości, nie zawierał substancji wymienionych w załączniku II; dopuszcza się nie więcej niż maksymalną wartość koncentracji wagowo w materiałach jednorodnych zgodnie z wyszczególnieniem w załączniku II. Na podstawie art. 6 ust. 1 przegląd i zmiana wykazu substancji objętych ograniczeniem w załaczniku II były rozpatrywane przez Komisję Europejską do 22 lipca 2014 r., a następnie okresowo z własnej inicjatywy lub na wniosek państwa członkowskiego UE; w celu dokonania przeglądu i zmiany załącznika II Komisja Europejska zwraca szczególną uwagę na to, czy substancja, w tym substancje w bardzo małych ilościach bądź o bardzo małej strukturze wewnętrznej lub powierzchniowej (dotyczy to nanomateriałów) ${ }^{36}$, bądź grupa podobnych substancji:

a) mogłyby mieć negatywny wpływ podczas gospodarowania zużytym sprzętem elektrycznym i elektronicznym, w tym na możliwości przygotowania

${ }^{34}$ Dz. Urz. UE L 197 z 24 lipca 2012 r., s. 38, ze zm.

35 Dz. Urz. UE L 174 z 1 lipca 2011 r., s. 88 ze zm.

36 Motyw 16 preambuły do rozporządzenia 2011/65/UE. 
zużytego sprzętu elektrycznego i elektronicznego do ponownego wykorzystania lub recyklingu materiałów pochodzących ze zużytego sprzętu elektrycznego i elektronicznego;

b) mogłyby doprowadzić, ze względu na swoje przeznaczenie, do niekontrolowanego lub rozproszonego uwolnienia do środowiska tych substancji lub powstania niebezpiecznych pozostałości, produktów ich przemiany bądź rozkładu w trakcie przygotowania do ponownego wykorzystania, recyklingu lub innego przetwarzania materiałów pochodzących ze zużytego sprzętu elektrycznego i elektronicznego;

c) mogłyby doprowadzić do niemożliwego do zaakceptowania narażenia pracowników zajmujących się zbiórką i przetwarzaniem zużytego sprzętu elektrycznego i elektronicznego;

d) mogłyby zostać zastapione substytutami lub alternatywnymi technologiami, które mają mniej szkodliwe skutki.

Rozporządzenie Parlamentu Europejskiego i Rady 66/2010/WE w sprawie oznakowania ekologicznego $\mathrm{UE}^{37}$, według art. 1, określa zasady ustanawiania i stosowania dobrowolnego programu oznakowania ekologicznego UE. Celem programu jest promocja produktów odznaczajacych się wysokim poziomem efektywności ekologicznej (motyw 5 preambuły); stwierdza się, że należy informować społeczeństwo i zwiększyć rozpoznawalność oznakowania ekologicznego UE za pomocą działań promocyjnych, kampanii informacyjnych i edukacyjnych na szczeblu lokalnym, krajowym i unijnym, aby kosnumenci mogli dokonywać przemyślanych wyborów (motyw 13 preambuły). Załączniki do decyzji: 2017/1214/UE ${ }^{38}, 2017 / 1215 / \mathrm{UE}^{39}, 2017 / 1216 / \mathrm{UE}^{40}, 2017 / 1217 / \mathrm{UE}^{41}$, 2017/1218/UE ${ }^{42}$ i 2017/19/UE ${ }^{43}$ stanowia, że w wykazie wszystkich substancji obecnych w składzie produktu należy wyraźnie zaznaczyć wszystkie substancje w postaci nanomateriałów, podając w nawiasie wyraz „nano” (lit. a).

Nadrzędnym celem oznakowywania obecności składników w formie nanomateriałów w produkcie jest zagwarantowanie swobody konsumentów w zakresie podejmowania w pełni świadomych decyzji o zakupie produktów ${ }^{44}$. Ponadto wśród substancji, których produkt nie może zawierać, niezależnie od ich

37 Dz. Urz. UE L 27 z 30 stycznia 2010 r., s. 1, ze zm.

${ }^{38}$ Decyzja Komisji 2017/1214/UE ustanawiająca kryteria oznakowania ekologicznego UE dla detergentów do ręcznego zmywania naczyń, Dz. Urz. UE L 180 z 12 lipca 2017 r., s. 1.

${ }^{39}$ Decyzja Komisji 2017/1215/UE ustanawiająca kryteria oznakowania ekologicznego UE dla detergentów do zmywarek do naczyń do zastosowań przemysłowych i instytucjonalnych, Dz. Urz. UE L 180 z 12 lipca 2017 r., s. 16.

40 Decyzja Komisji 2017/1216/UE ustanawiająca kryteria oznakowania ekologicznego UE dla detergentów do zmywarek do naczyń, Dz. Urz. UE L 180 z 12 lipca 2017 r., s. 31.

${ }^{41}$ Decyzja Komisji 2017/1217/UE ustanawiająca kryteria oznakowania ekologicznego UE dla środków do czyszczenia powierzchni twardych, Dz. Urz. UE L 180 z 12 lipca 2017 r., s. 45.

${ }^{42}$ Decyzja Komisji 2017/1218/UE ustanawiająca kryteria oznakowania ekologicznego UE dla detergentów przeznaczonych do prania, Dz. Urz. UE L 180 z 12 lipca 2017 r., s. 63.

${ }^{43}$ Decyzja Komisji 2017/1219/UE ustanawiająca kryteria oznakowania ekologicznego UE dla detergentów przeznaczonych do prania do zastosowań przemysłowych i instytucjonalnych, Dz. Urz. UE L 180 z 12 lipca 2017 r., s. 79.

${ }^{44}$ E. Stokes, Nanotechnology and the Products of Inherited Regulation, „Journal of Law and Society" 39(1), 2012, s. 109. 
stężenia, jest wymienione nanosrebro (kryterium 4 lit. a załączników do decyzji: 2017/1214/UE, 2017/1215/UE, 2017/1217/UE i 2017/1219/UE oraz kryterium 5 lit. a załączników do decyzji: 2017/1216/UE i 2017/1218/UE). W odniesieniu do nanosrebra dowody sugeruja, że stwarza ono potencjalne ryzyko dla środowiska ${ }^{45}$.

Decyzja 2016/1349/UE ${ }^{46}$ stanowi, że nie dopuszcza się stosowania nanosrebra (zawartego w produkcie biobójczym w rozumieniu art. 3 ust. 1 lit. a rozporządzenia Parlamentu Europejskiego i Rady 528/2012/UE w sprawie udostępniania na rynku i stosowania produktów biobójczych ${ }^{47}$ ) podczas transportu lub przechowywania produktu, któregokolwiek z wchodzących w jego skład wyrobów lub jakiejkolwiek jego jednorodnej części; nie może ono być wprowadzane do produktu końcowego ani opakowania produktu (dodatek tabela 1 lit. e).

Decyzja 2014/893/UE ${ }^{48}$ (załącznik kryterium 3 lit. a) stanowi, że nanosrebro nie może być obecne w składzie produktu ani jako część składu, ani jako część mieszaniny zawartej w składzie. Decyzja 2014/763/UE ${ }^{49}$ (załącznik pkt 6.6) rozstrzyga, że cząstek nanosrebra nie dodaje się w sposób zamierzony do produktu, do jakiejkolwiek jego jednorodnej części, ani do wchodzacych w jego skład materiałów. Decyzja 2014/350/UE ${ }^{50}$ (załącznik tabela e), w ramach ograniczeń mających zastosowanie do procesów wykończeniowych, także stanowi, iż nie wprowadza się biocydów do włókien, tkanin lub produktu końcowego w celu nadania im właściwości biobójczych, powszechny zaś przykład to nanosrebro.

Kryterium 5 załącznika do decyzji 2014/312/UE ${ }^{51}$ określa ograniczenia dotyczące substancji i mieszanin niebezpiecznych:

a) ograniczenia ogólne mające zastosowanie do klasyfikacji pod względem zagrożeń;

b) ograniczenia majace zastosowanie do substancji stanowiacych bardzo duże zagrożenie;

c) ograniczenia mające zastosowanie do określonych substancji niebezpiecznych.

W zakresie ograniczeń ogólnych kryterium 5 lit. a stanowi, że receptura produktu końcowego, obejmująca wszystkie celowo dodane składniki wystę-

${ }^{45}$ Milieu Ltd., AMEC Environment \& Infrastructure UK Ltd., op. cit.

${ }^{46}$ Decyzja Komisji 2016/1349/UE ustalająca kryteria ekologiczne przyznawania oznakowania ekologicznego UE dla obuwia, Dz. Urz. UE L 214 z 9 sierpnia 2016 r., s. 16.

${ }_{47}$ Dz. Urz. UE L 167 z 27 czerwca 2012 r., s. 1 ze zm.

${ }^{48}$ Decyzja Komisji 2014/893/UE ustalająca ekologiczne kryteria przyznawania oznakowania ekologicznego UE produktom kosmetycznym spłukiwanym, Dz. Urz. UE L 354 z 11 grudnia 2014 r., s. 47 ze zm.

${ }^{49}$ Decyzja Komisji 2014/763/UE ustalająca ekologiczne kryteria przyznawania oznakowania ekologicznego UE pochłaniającym środkom higienicznym, Dz. Urz. UE L 320 z 6 listopada 2014 r., s. 46 .

${ }^{50}$ Decyzja Komisji 2014/350/UE ustalająca kryteria ekologiczne przyznawania oznakowania ekologicznego UE dla wyrobów włókienniczych, Dz. Urz. UE L 174 z 13 czerwca 2014 r., s. 45 ze zm.

${ }^{51}$ Decyzja Komisji 2014/312/UE ustanawiająca ekologiczne kryteria przyznawania oznakowania ekologicznego UE farbom i lakierom wewnętrznym i zewnętrznym, Dz. Urz. UE L 164 z 3 czerwca 2014 r., s. 45 ze zm. 
pujące w stężeniu większym niż $0,010 \%$ nie zawiera substancji lub mieszanin sklasyfikowanych jako toksyczne, niebezpieczne dla środowiska, działające uczulająco na układ oddechowy lub skórę bądź rakotwórcze, mutagenne lub działające szkodliwie na rozrodczość zgodnie z rozporządzeniem CLP; kryterium 5 lit. a zawiera także odstępstwa mające zastosowanie do grup substancji. Wnioskodawca, wykazując zgodność z tym kryterium, powinien scharakteryzować substancje i mieszaniny według sekcji 10, 11 i 12 załącznika II do rozporządzenia REACH (wymagania dotyczące sporządzania kart charakterystyki); musi to obejmować również informacje dotyczące postaci fizycznej i stanu składników oraz identyfikację wytworzonych składników w formie nanomateriałów, w przypadku których co najmniej 50\% cząstek w liczbowym rozkładzie wielkości cząstek ma co najmniej jeden wymiar zewnętrzny w zakresie $1 \mathrm{~nm}-100 \mathrm{~nm}$.

Decyzja 2011/381/UE52 (załącznik kryterium 1 lit. a) rozstrzyga, że produkt ani żadna z jego części nie może zawierać substancji (w jakiejkolwiek formie, $\mathrm{w}$ tym $\mathrm{w}$ formie nanomateriałów) spełniających kryteria klasyfikacji do zwrotów (wymienionych w ramach kryterium 1 lit. a) określających zagrożenie zgodnie z rozporządzeniem CLP ani substancji, o których mowa w art. 57 rozporządzenia $\mathrm{REACH}$ - są to:

a) substancje spełniajace kryteria klasyfikacji w klasie zagrożenia „rakotwórczość" kategorii 1A lub 1B zgodnie z rozporządzeniem CLP;

b) substancje spełniające kryteria klasyfikacji w klasie zagrożenia „działanie mutagenne na komórki rozrodcze" kategorii 1A lub 1B zgodnie z rozporządzeniem CLP;

c) substancje spełniające kryteria klasyfikacji w klasie zagrożenia „działanie szkodliwe na rozrodczość” kategorii 1A lub 1B, „działanie szkodliwe na funkcje rozrodcze i płodność lub na rozwój” zgodnie z rozporządzeniem CLP;

d) substancje trwałe, wykazujące zdolność do bioakumulacji i toksyczne według kryteriów zawartych w rozporządzeniu REACH;

e) substancje bardzo trwałe i wykazujące bardzo dużą zdolność do bioakumulacji, według kryteriów zawartych w rozporządzeniu REACH;

f) inne substancje, tj. substancje zaburzające gospodarkę hormonalną lub substancje trwałe, toksyczne, wykazujące zdolność do bioakumulacji lub też substancje bardzo trwałe, wykazujące bardzo dużą zdolność do bioakumulacji, niespełniające kryteriów zawartych w lit. d lub e, w odniesieniu do których istnieją naukowe dowody prawdopodobnych poważnych skutków dla zdrowia ludzkiego lub dla środowiska dające powody do obaw równoważnych obawom stwarzanym przez pozostałe substancje wymienione w lit. a-e i które są identyfikowane w każdym przypadku indywidualnie.

Względem form nanomateriałów, które celowo dodano do produktu, należy udowodnić zgodność z kryterium 1 lit. a w odniesieniu do każdego stężenia. Stężenia graniczne dla substancji spełniających kryteria art. 57 lit. a, b lub c rozporządzenia REACH nie przekraczają 0,010\% (wartość procentowa masy).

52 Decyzja Komisji 2011/381/UE ustanawiająca kryteria ekologiczne przyznawania oznakowania ekologicznego UE smarom, Dz. Urz. UE L 169 z 29 czerwca 2011 r., s. 28 ze zm. 
Odstępstwa od kryterium 1 lit. a zawiera tabela 1. Wnioskodawca ma obowiązek dostarczyć właściwemu organowi dokładny skład produktu i wykazać zgodność substancji zawartych $\mathrm{w}$ produkcie $\mathrm{z}$ kryterium 1 lit. a na podstawie informacji obejmujacych co najmniej informacje określone w załączniku VII do rozporządzenia REACH; takie informacje są charakterystyczne dla określonej formy substancji zastosowanej w produkcie, w tym formy nanomateriałów.

\section{PODSUMOWANIE}

Możliwość umieszczenia nanomateriałów na liście obserwacyjnej substancji, w odniesieniu do których mają być gromadzone dane z monitorowania w celu szeregowania substancji do dokonania przeglądu Wykazu substancji priorytetowych w dziedzinie polityki wodnej (art. 8b ust. 1 dyrektywy 2008/105/WE), ewentualność uwzględnienia nanomateriałów zawartych w sprzęcie elektrycznym i elektronicznym w ramach selektywnego przetwarzania materiałów i części składowych zużytego sprzętu elektrycznego i elektronicznego (art. 8 ust. 4 dyrektywy 2012/19/UE), a także możliwość zakwalifikowania nanomateriałów do substancji objętych ograniczeniem stosowania w sprzęcie elektrycznym i elektronicznym (art. 6 ust. 1 dyrektywy 2011/65/UE) służą minimalizowaniu ryzyka wykorzystywania nowatorskich aplikacji nanotechnologii dla zdrowia ludzkiego i środowiska. Wymienione przepisy, wprowadzone w ostatnich latach, nie znalazły jak dotą praktycznego zastosowania w odniesieniu do nanomateriałów. Brak innych przepisów szczególnych dotyczących ochrony środowiska w kontekście stosowania nanomateriałów wynika zwłaszcza z niedoboru wiedzy naukowej w odniesieniu do ryzyka wiążącego się z nanotechnologią. Rozporządzenie REACH jest ogólnym aktem prawnym mającym zastosowanie do substancji chemicznych $\mathrm{w}$ formie nanomateriału i podstawa informacji na temat ryzyka związanego z produkcją i korzystaniem z nanomateriałów - według komunikatu Komisji Europejskiej „Aspekty regulacyjne nanomateriałów”. Ponadto klasyfikacja zagrożenia na podstawie rozporządzenia CLP pozwala zidentyfikować zanieczyszczenia środowiska - jak stanowi komunikat Komisji Europejskiej „Drugi przegląd regulacyjny poświęcony nanomateriałom”. Zarówno rozporzadzenie REACH, jak i rozporządzenie CLP nie są dostosowane do nietypowych właściwości, którymi odznaczają się nanomateriały. Wynika to z faktu, że wymagania rozporządzenia REACH w odniesieniu do rejestracji chemikaliów i zakresu informacji na ich temat opierają się na ilości substancji chemicznej, nie wyrażając należycie specyficznych właściwości nanomateriałów. Klasyfikacja zagrożenia na podstawie rozporządzenia CLP także nie uwzględnia swoistych cech nanomateriałów.

dr Marcin Jurewicz

Politechnika Białostocka

m.jurewicz@pb.edu.pl 


\section{NANOTECHNOLOGY AND ENVIRONMENTAL PROTECTION - LEGAL MECHANISMS}

\section{Sum mary}

EU legal regulations address environmental protection in terms of the application of nanotechnology only in a fragmented, piecemeal manner. The assurance of the possibility of placing nanomaterials on the watch list of substances for which the monitoring data for substance serialisation is to be collected for a review of the List of priority substances in the field of water policy (Article 8b section 1 of Directive 2008/105/EC), the possibility of taking into account nanomaterials contained in electrical and electronic equipment under the selective processing of materials and components of waste electrical and electronic equipment (Article 8 section 4 of Directive 2012/19/EU), and the possibility of classifying nanomaterials into restricted substances in electrical and electronic equipment (Article 6 section 1 of Directive 2011/65/EU) serve to reduce the risk of using innovative nanotechnology applications for human health and the environment. As a consequence of the lack of scientific knowledge underpinning environmental regulation, including the techniques for the detection, measurement and characterisation of nanomaterials and their monitoring and the lack of data on their toxicity, nanomaterials continue to be underregulated. 
